Article

\title{
From an Enclosure to the Corraleja. An Analysis of the Genesis of an Ephemeral and Vernacular Colombian Architecture
}

\author{
Massimo Leserri ${ }^{1}$ (i), Merwan Chaverra Suarez ${ }^{1}$, Gabriele Rossi ${ }^{2, *(1)}$ \\ and Dayan Ariadna Guzman Bejarano ${ }^{3, *}$ \\ 1 Gica Group, Faculty of Engineering and Architecture, Pontifical Bolivarian University, Z.C. 230002 Monteria, \\ Colombia; massimo.leserri@upb.edu.co (M.L.); merwan.chaverra@upb.edu.co (M.C.S.) \\ 2 Dicar, Faculty of Architecture, Polytechnic University of Bari, Z.C. 70100 Bari, Italy \\ 3 Cavida Group, Faculty of Social and Human Sciences, Pontifical Bolivarian University, \\ Z.C. 230002 Monteria, Colombia \\ * Correspondence: gabriele.rossi@poliba.it (G.R.); dayan.guzmanb@upb.edu.co (D.A.G.B.)
}

Received: 4 December 2017; Accepted: 23 February 2018; Published: 13 March 2018

\begin{abstract}
In the Colombian Caribbean region, human extraordinary ability to interpret nature's functioning and mechanical language, has allowed man to manage and use, throughout history, natural elements to improve living conditions. In Architecture, technical-constructive knowledge development has enabled constructions of a temporary and stable nature. In fact, this research project begins with the relationship between the understanding of nature and the creation of Colombian vernacular architecture, which has led to a special and unique form of architecture such as the Corraleja. In this architecture, vernacular constructive tradition and ephemeral character are concurremt. This has been an object of interest due to its folkloric aspects, however, it has rarely been researched for its architecture. Currently, it is usually built only when its real spatial function is needed, becoming a place destined to contain the annual bullfighting-like festivities. In fact, its limited and cyclical permanence, gives it an ephemeral and also nomadic character since it is not always built, necessarily, in the same place. This research study begins by means of the importance of the vertical balance control of the alive branches nailed in the ground, still present in the whole Caribbean region through enclosures. This can be considered as a primordial action and conquest, and has allowed the realization of every vernacular construction. In Europe, the tradition of ephemeral architecture when there are some civil and religious festivities becomes stable architecture over time; bullfighting party in Spain is an emblematic case which is transformed into stable spaces such as bullrings. This tradition extends to the Spanish colony in America in the eighteenth century. In the Colombian Caribbean, for example, the bullfighting festival keeps an ephemeral character that is fed by a vernacular architectural tradition. In addition, existing literature on the vernacular theme suggests that, from long time ago, many examples of tectonic building (a set of finite or pseudo-finite elements such as branches, trunks, etc.) have been nomadic, self-constructed, anonymous and with an emergency appearance which have become stable, just after many constructions, by losing all ephemeral characteristics. Likewise, to understand the Corralejas' genesis, observing the history of European architecture has been necessary due to the several old associated experiences of transitory constructions, e.g., with recreational spaces, religious or civil celebrations. This study is based on different research methodologies such as drawings of existing cases and bibliographic and iconographic analyzes. This has also been developed through a compulsory contrast with the ancient architecture of bullfighting shows, to formulate morphological reflections and analogies and analyze their ephemeral condition. Today, the Corraleja survives in Colombia, representing an architectural oddity that must be safeguarded not only for its vernacular essence but also for its limited temporal condition. In fact, tectonics, the art of montage, reconfirms the connection allowing its existence and representing a surprising and unique set of values that must
\end{abstract}


be defended and treated as an architectural heritage. After the analysis on the Corralejas genesis, the study will continue through several forms of survey to explore and define constructive aspects in a different scale of detail.

Keywords: enclosures; architecture; ephemeral; vernacular; corralejas; Colombia; time; construction

\section{Introduction}

Along with increasing interest in preservation of stable heritage architecture, usefully destined for defining territory's image and identity, important and amazing, but time-limited architectural forms survive. (In Figure 1, traditional construction that still survives in the Colombian Caribbean). Therefore, they could be described as ephemeral [1]. These architectures are often done cyclically, i.e., they are proposed in the same place, with the same aspects, every time. They are artifacts not only having an essential relationship with time but also with constructive aspects, that characterize their possibility of being built and demolished.

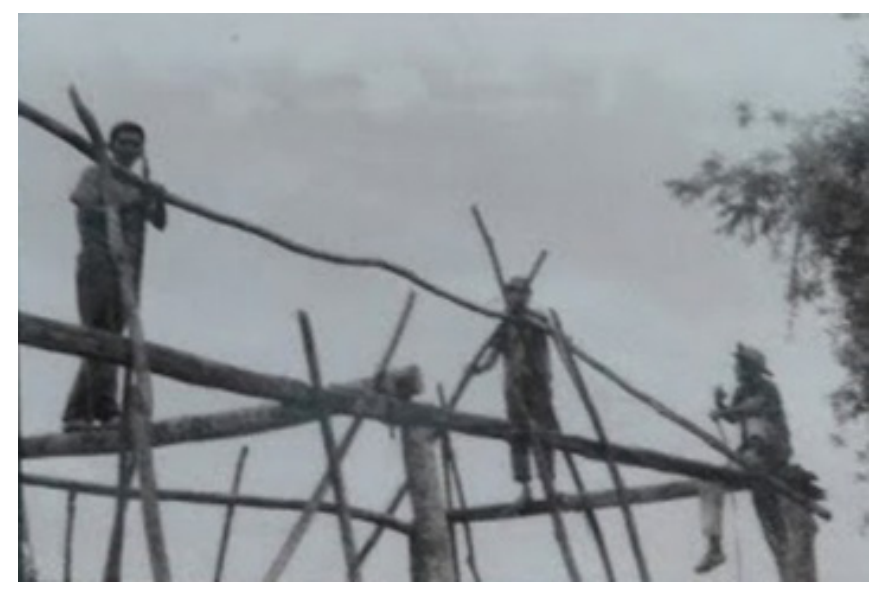

Figure 1. Old picture of a vernacular construction in Cordoba. Centro de Documentación Regional Orlando Fals Borda-Banco de la República Montería. Folder p. 23 [2].

This architecture survives in the Caribbean region in Colombia, where constructive tradition is inherited from a knowledge related to concepts of assembly and disassembly that portrays the Caribbean vernacular architecture.

Throughout the region, particularly in Cordoba Department, landscape constantly shows humans' extraordinary ability to rightly position natural elements which serve to create spatial relationships [3]. (In Figure 2, barra de humo wood stick, a natural element used in Cordoba Department). 


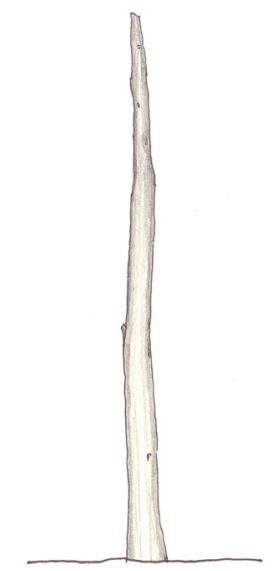

Figure 2. Drawing of a stick vertically placed on the ground (barra de humo wood). Source. Massimo Leserri, 2017 [4].

To a certain extent, man has been able to manage natural elements and do research on how nature works, understanding that there are possibilities to determine what is needed for life as well as to develop practical forms (techniques). 'Control of vertical balance' is confirmed in the landscape as the first activity and practical conquest enduring still today; and it is recognized through several types of barriers and horizontal lines formed by "living" ground-embedded branches, (In Figure 3, sticks of alive branches in vertical position compose the landscape of Cordoba Department) seemingly representing origin and true form to re-order nature and meet a need [5].

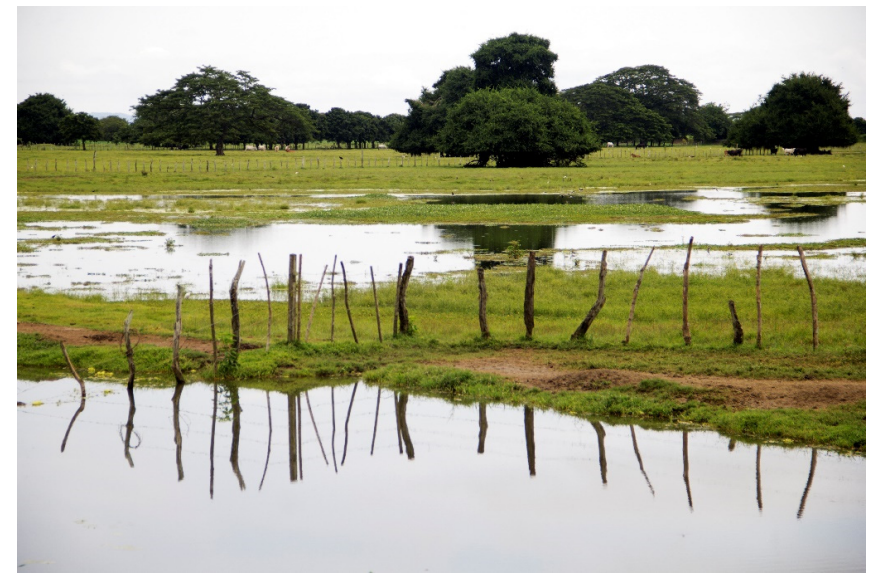

Figure 3. Distinctive picture of the Cordoba Landscape. Source: Massimo Leserri, 2017 [4].

Wall birth seems to determine, regarding permeability degree, separation levels with the exterior, looking entirely like a sapient play enclosure [6]. (In Figure 4, fences of alive branches make up permeable enclosures) Wooden construction is always a light, serial, transparent and permeable work. An ensemble of finite or pseudo-finite elements (branches, trunks, etc.), wherein tectonics restates itself as the art of assembly, i.e., the connection not only of construction pieces, but also of nomadic objects.

Difference among enclosures is only a matter of infinite morphologic variables; however, for this study it is useful to point out the ideal formula of the circular enclosure that geometric intuition allows to achieve. The ancestral and overriding security requirement of human beings to create a protection against animals is evident. For example, an illustration of an armed man with a branch in his hand who, surrounding himself around 360 degrees, defends his integrity when feeling attacked. The man learns the circular movement and form by applying a circular shape when delimiting space through a physical barrier or fire circle to protect himself. But the circle is also the form of his group or family 
around the sacred fire. The last one, as Semper indicates, is considered one of the four patterns of the house which is pictured through the image of the Caribbean hut (in Figure 5, structural trunks joined to live branches of the wall).
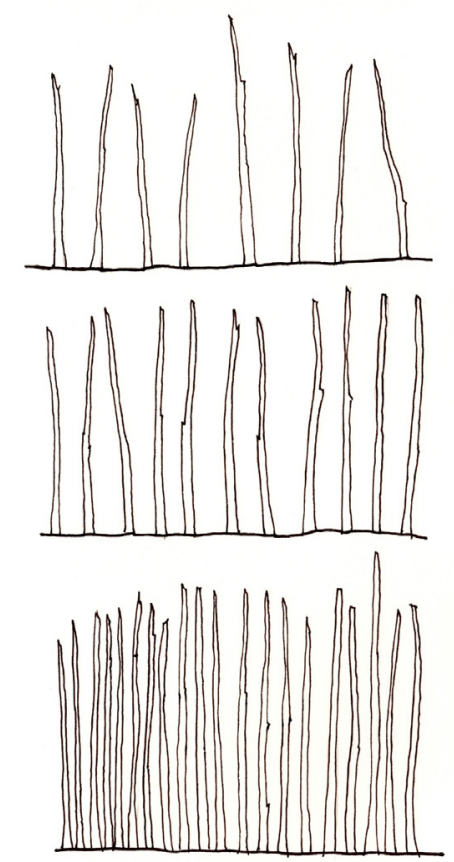

Figure 4. Graphic study on permeability on fences found in the Cordoba landscape. Source: Massimo Leserri, 2017 [4].
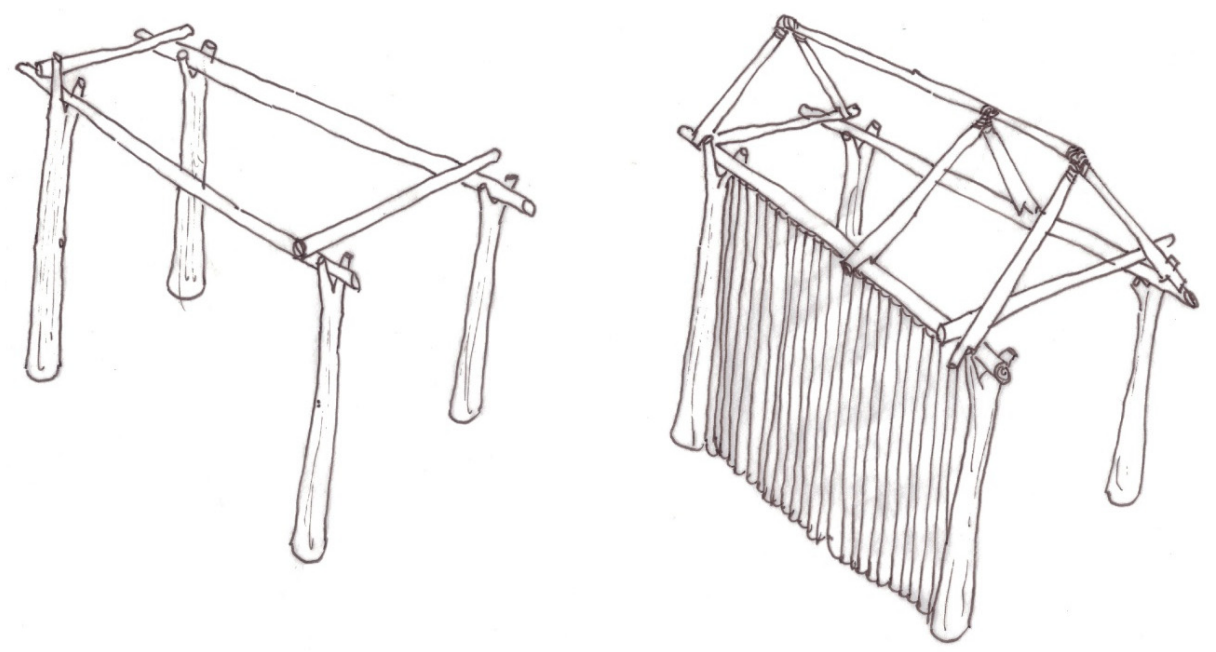

Figure 5. Study on the assembly of the Cordoba Vernacular cabin. Source: Massimo Leserri, 2017 [4].

In fact, the circular enclosure later defined as "el corral" [7], has validity because of its practical characteristics, such as external convexity that promotes a constructive resistance and sight economy. There are different views: the first one, from center to perimeter (to facilitate total control) and the second one, from any part of the perimeter to the center that is identified as the epicenter of the 'mystical scene'. Bull festivals are a symbol of this, as Hemingway describes it, 'the nature of dread and bravery' [8]. (In Figure 6, a spontaneous brave person puts the banderillas to the bull in a traditional Corraleja) Therefore, the enclosure is progressively conceived for new usages not only domestic, but 
also public, religious and festive; and the word "el Corral" provides the root for "Corralejas" which is known as the bullfighting festival within it. This study has been developed through several graphic representing forms, and bibliographic and iconographic analysis.

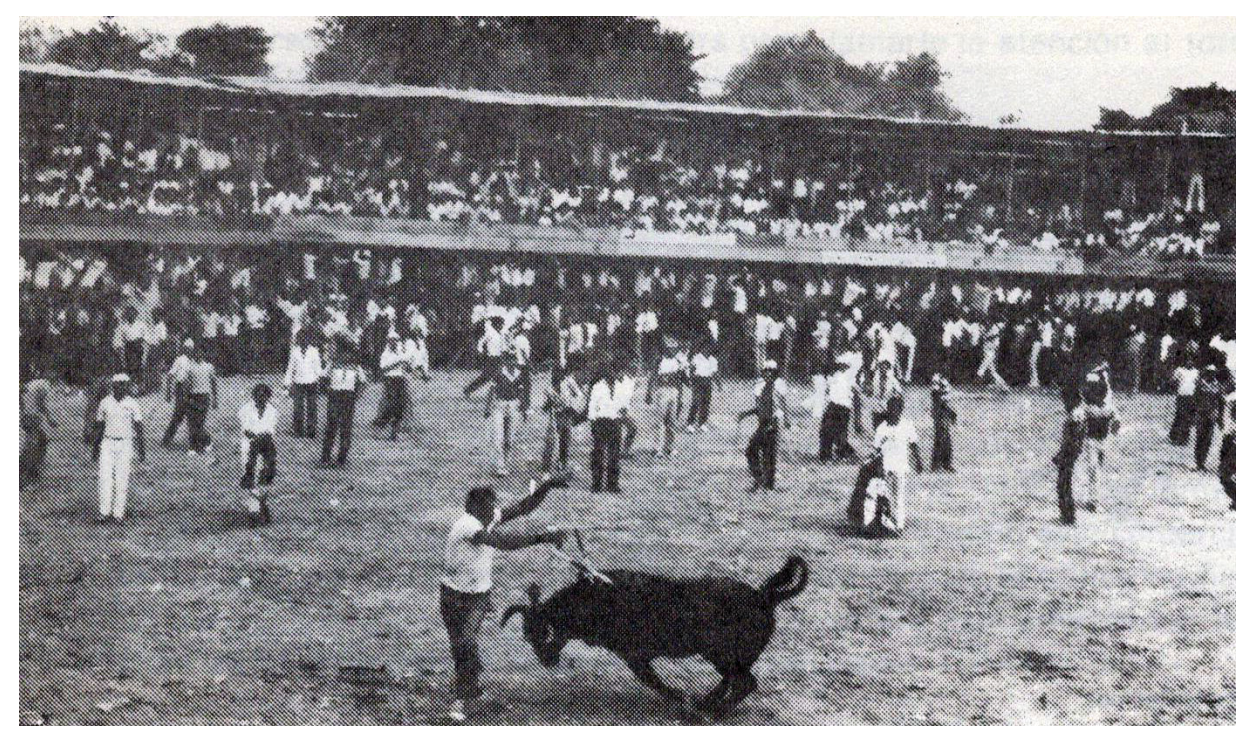

Figure 6. Old photograph showing elements of the Corraleja festival. Source: Santana Vega J.A (1986). in "El Mundo de La Corraleja", editorial Graficas Corsa of Monteria, page 58 [9].

\section{Results}

This paper deepens the study of the Corraleja's vernacular architecture, because there is no research so far to approach the vision of the architectural value, but rather just the folkloric feast. The study shows characteristic elements of this original architecture in the Colombian Caribbean region through comparisons with experiences of similar architectures; and an analysis of the Cordoba construction tradition; these results are a starting point for future research through scientific survey of the main Corralejas from the region.

\section{Discussion}

The "Corralejas" as a cultural representation of the lands from the valleys and savannahs of the Sinu and San Jorge rivers in the Colombian Caribbean region, has a strong popular tradition from its beginnings at the end of the 19th century [10]. Its vernacular architecture of popular tradition is perfectly comparable to Christopher Alexander's definition [11] of an ideal architecture, where characteristics such as timelessness and interaction between space and events must mainly be met. It is something that it is obtained with the precision and usage of the always present "language patterns" that are always there in what is called the "timeless way of building". (In Figure 7, the craftsmanship of the Vueltiao hat as a cultural and traditional representation of circular shapes in Cordoba Department).

The presence of "cultural patterns" in the construction of the Corraleja is the basis for making it an authentic and original architectural expression from the Colombian Caribbean region. Its center-polygonal constructive technique with vertical elements (wood slats) and horizontal pieces (madrines), spliced and assembled, is a practice that follows ancestral techniques related to weaving laws. (In Figure 8, union of natural elements with bejuco in a Corraleja) It is possible for these to be popular techniques connected to textile art, then transposed to the Corraleja assembly. This is a present quality in the four elements of Semper's architecture [12], i.e., building the Corraleja is possible for a Cordoba's inhabitant because it is like making a handicraft work such as weaving a tapestry. Because he uses his constructive knowledge and developed techniques over time, they are also useful to set up other kinds of structures such as vertical looms in the field. 


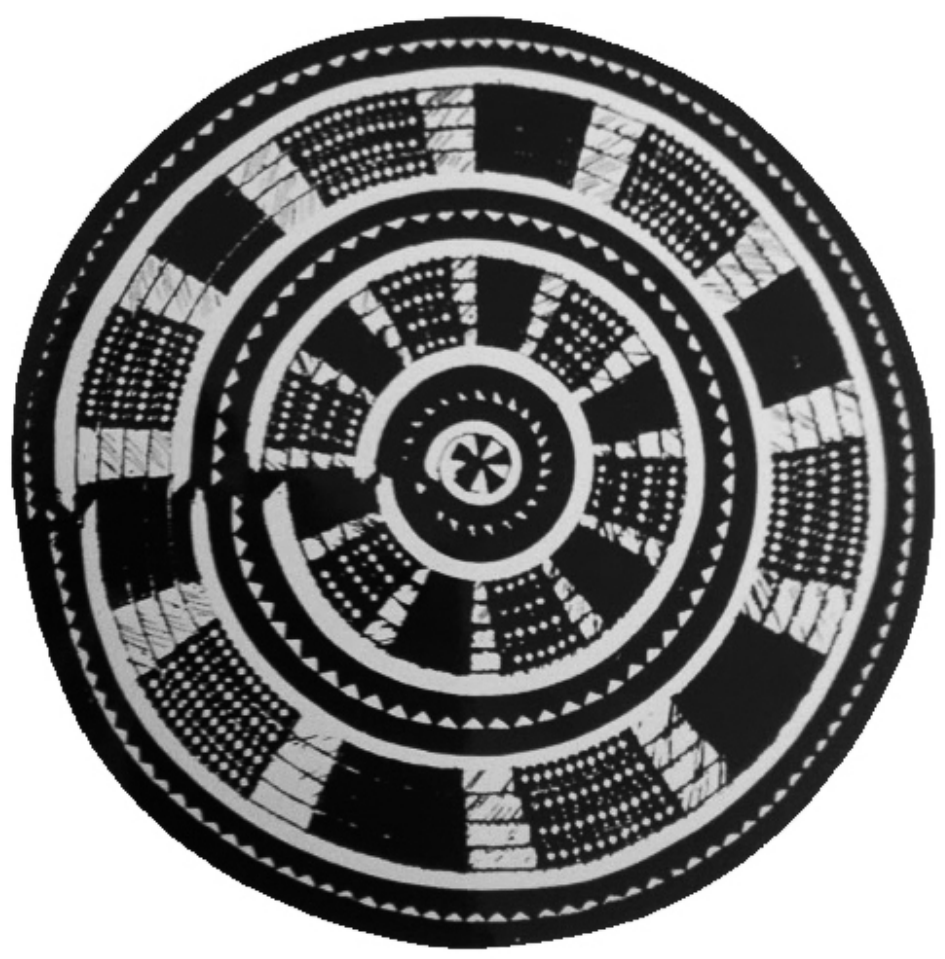

Figure 7. Vueltiao hat image, typical expression of Cordoba's artisanal work. Source: Centro de Documentación Regional Orlando Fals Borda-Banco de la República Montería. Folder p. 23 [2].

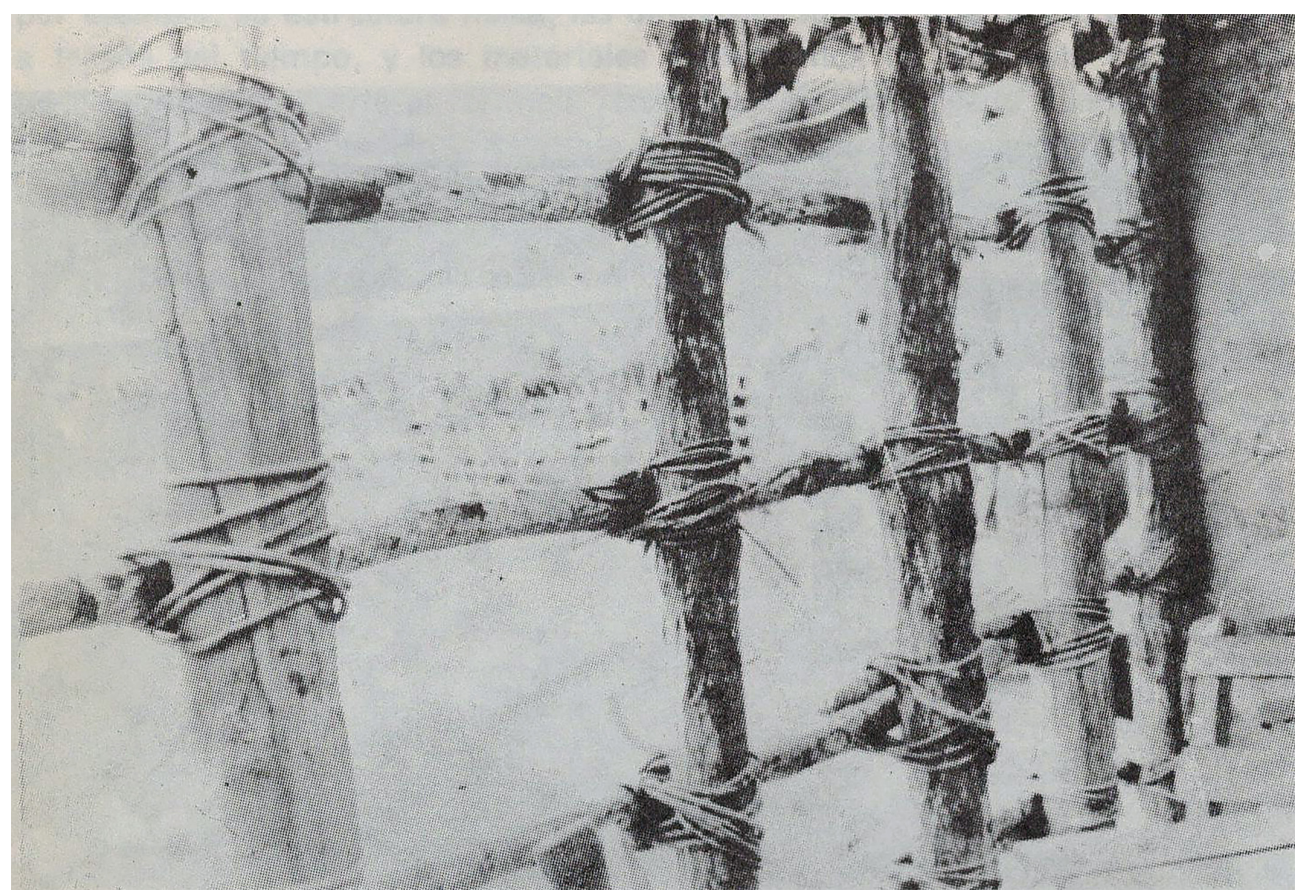

Figure 8. Image on the manual ability to solve, through braiding (bejuco), the union between natural elements. Source: Santana Vega J.A. (1986) in "El Mundo de La Corraleja", editorial Graficas Corsa of Monteria, page 58 [9].

Nowadays, the Corraleja assembling process begins on an epicenter, with a fifty-meter average radial stroke and axes distributed every fifteen meters, where approximately twenty-two modules 
spread over a linear perimeter of three hundred meters are circumscribed. Each module has an installation of wood slats (material: vara de humo), making a reticular loom formed by five bays in one direction and nine bays in another direction. The bays are articulated by madrines. These are caracoli, namely planks which form banisters and benches that profile a stand (semi-circle module formed by the union of all the modules); a very similar form to the bullring typology [13]. (See Figure 9)

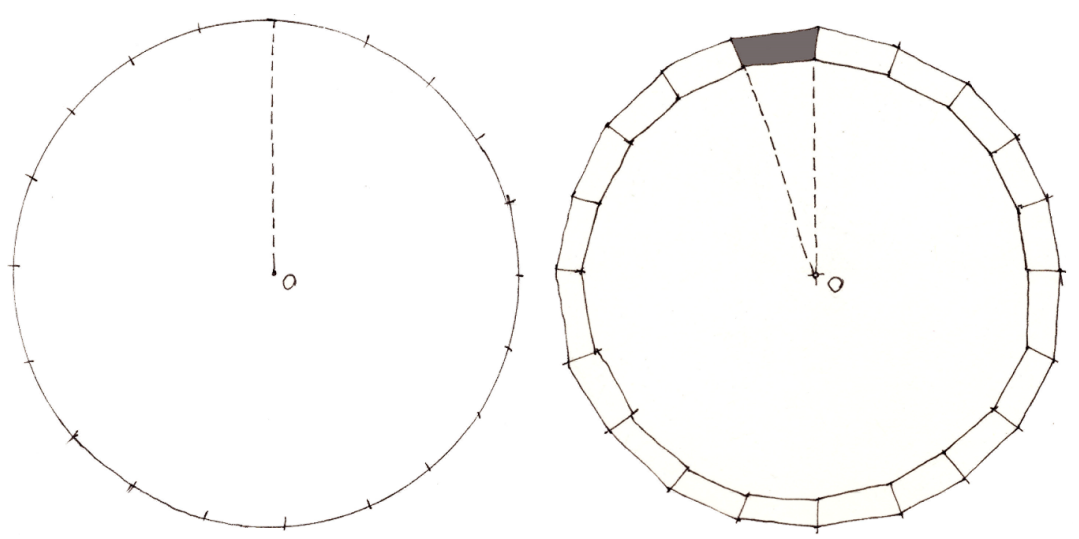

Figure 9. Drawing on the initial circular stroke for the assembly of the Corraleja, and the definition of the polygonal line through the determination of the basic module (palco) of the Corraleja. Source: Massimo Leserri, 2017 [4].

However, the ideal form of the circumference cannot be achieved for reasons that are implicit in the limited time of assembly and disassembly, such as the lack of means to transform and domesticate the nature of the Cordoba landscape itself. (See Figure 10) Consequently, it is necessary to review some cases in the architecture's history, as well as the bullrings' typology. (In Figure 11, assembly of a Corraleja with the main constructive elements that make it up)

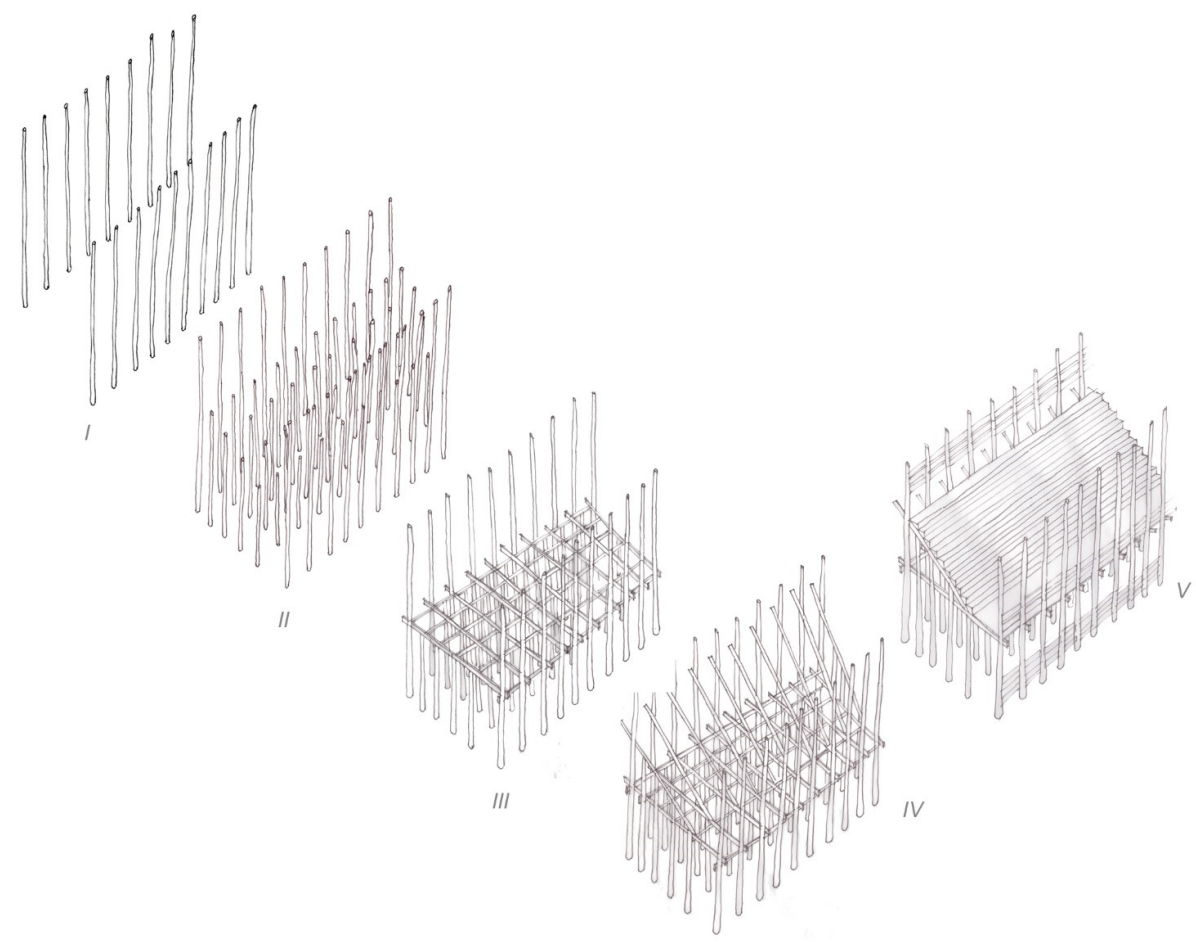

Figure 10. Representation of the assembly sequence of the modular unit (palco) of the Corraleja. Source: Massimo Leserri, 2017 [4]. 


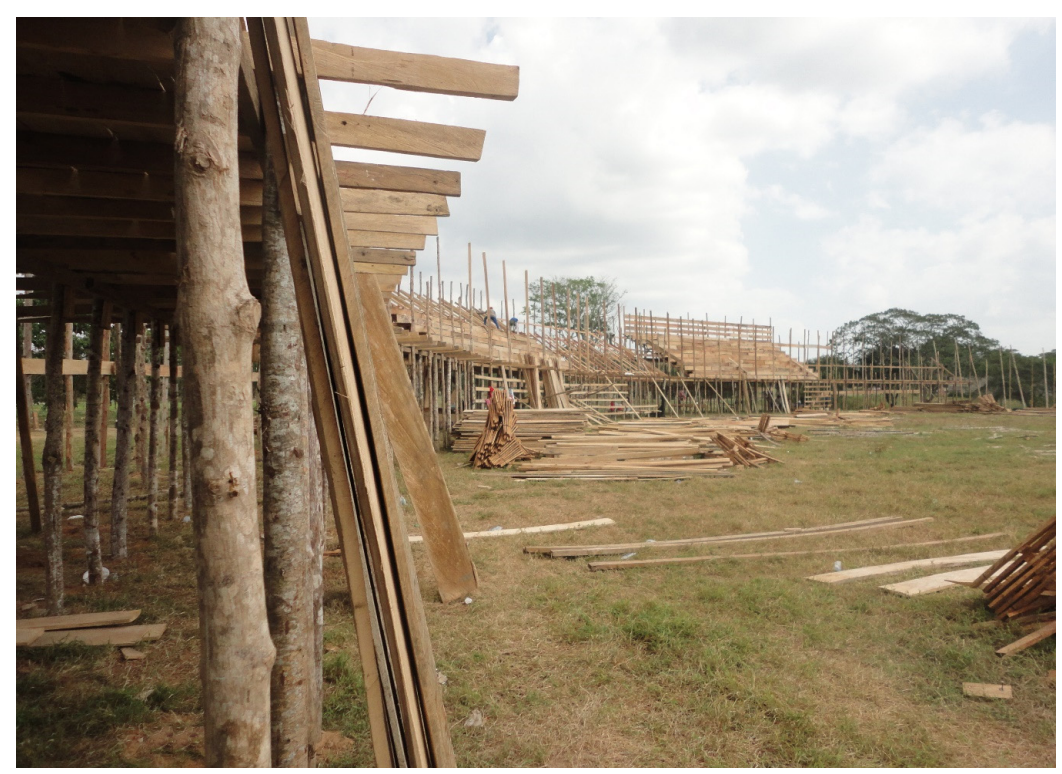

Figure 11. Image of the assembling of a Corraleja, where the main constructive elements are evident. Source: Merwan Chaverra, 2017 [14].

History suggests several examples where circular shapes persist in spectacle architecture, from the well-known Romans to the last bullrings' experiences. Therefore, we trace a correlation between the circular shape of the "bullring" and Roman architecture. There are two amphitheaters located in France supporting these hypotheses: Nimes and Arles, reused for bullfighting shows in more recent times [15].

The "Plaza de toros" circular shape is sometimes closely linked to the evolution of the bullfighting festival, which has developed into a show of struggle and combat, from its beginnings as an equestrian performance. In fact, the first events took place in public squares enabled for the occasion. First structures had a quadrangular shape that was better suited to the equestrian show. The plan "Plano de la plaza de San Francisco preparada con la tribuna para la plaza de toros" in Seville (anonymous watercolor of $1730 \mathrm{kept}$ in the municipal archive) shows, in the quadrangular public space, a wooden scenery with tiers and stages defining the festival enclosure through the integration or super-position with the square's architecture [16] (See Figure 12). The anonymous outlook of the watercolor of 1730, preserved in the municipal archives of Seville, is a rare image of the ephemeral staging of the bull's feast, because it is still quadrangular. 


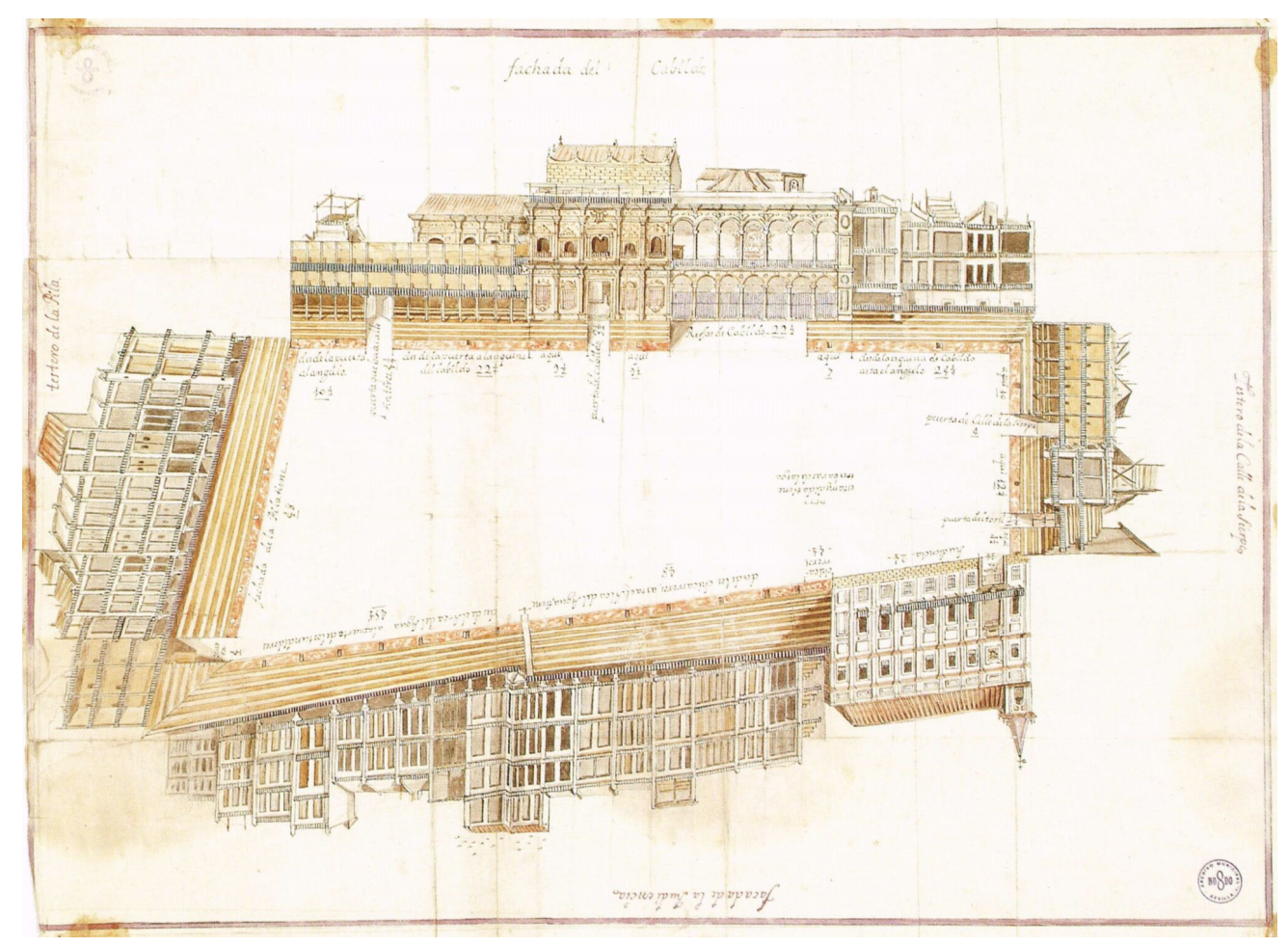

Figure 12. Plan of the Plaza de San Francisco made with the tribune for bullring in Seville. Source: Anonymous watercolor of 1730, municipal archive of Seville in Gentil Baldrich, J. M. et al., Rito y Fiesta: una aproximacion a la arquitectura efimera sevillana, Sevilla, Spain [16].

Only in the second half of the 18th century was there a progressive transition towards circular solutions, which were better suited to the evolution of the "corridas" spectacle thanks to the renewed interest in neoclassical culture boosted by findings of the Roman era [17]. These models, quadrangular squares before, and circular shapes later, were also extended into the Spanish colonies such as in Mexico [18], and generally in South American countries such as Colombia, where Corraleja, the subject of this study, represents a direct expression [19].

First installations in European and Latin American public squares were mobile. They were essentially constituted by a quadrangular enclosure structured with stages and tiers to welcome the public. Then, they became permanent architectural forms over time. Rectangular buildings, especially those from the initial stage, were made of wooden structures in public places, such as the Corraleja of today. They allow for some analogies in the festival's ephemeral architecture, perhaps more consistent than those which were sought with the circular architectures for spectacles in the Roman era.

In fact, there is a rich tradition of equestrian events and knightly tournaments organized during civil or religious celebrations. The festival iconography, which gives us a representation of the ephemeral event by bringing it to us, shows some scenographies with the theme of the enclosure that house the most chivalrous and playful events and many spectators in the stages and steps. In Europe, streets and squares of cities are the places generally used for festivals, where the enclosure is the space for entertainment. It is an open-air theater of demonstrations with an equestrian tournament nature in its majority, but also with characters of mythological and/or historical reconstructions, often under the form of parody.

The drawing of G.B. Teatro Coriolano of the Tournament for the Liberation tentata de Venere, done in Bologna (Italy), on 20 March 1628, shows a rectangular perimeter with semicircles on the short sides. It is structured on three levels at length and has a stage in the hemicycle in the background. In the center, the scene is occupied by an equestrian event with some knights and horses. (See Figure 13) 


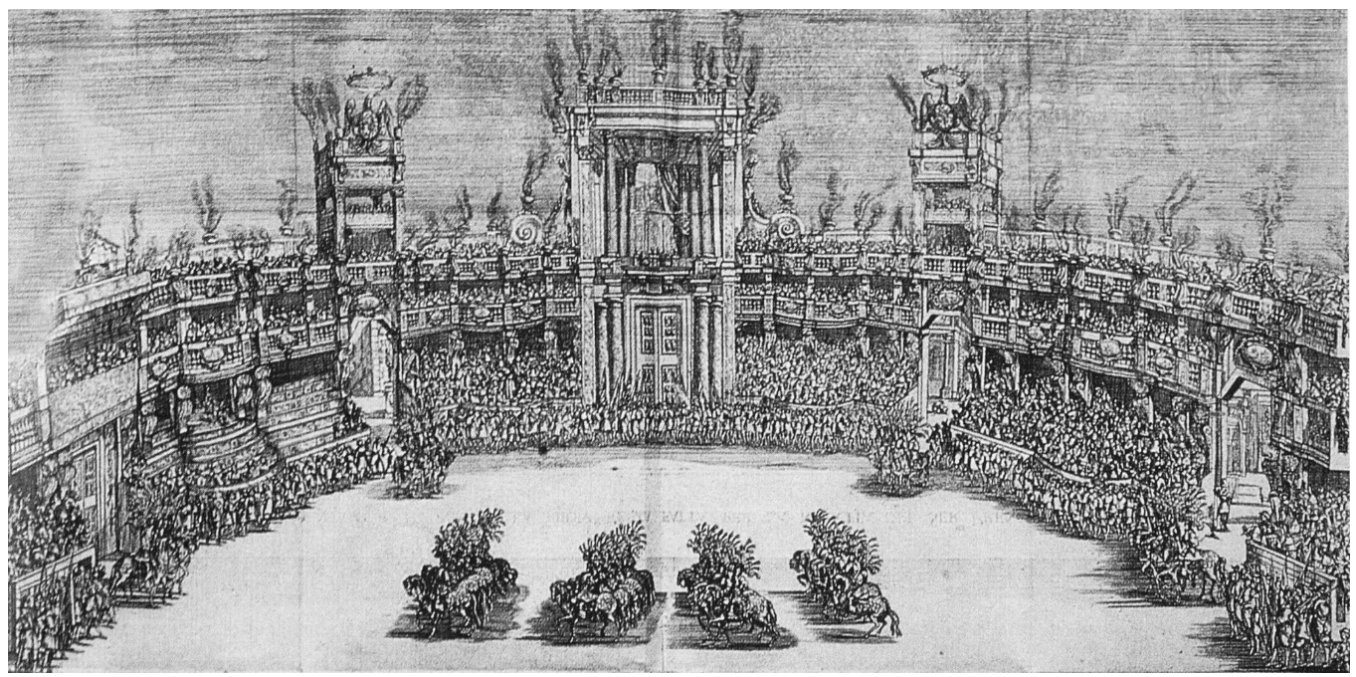

Figure 13. Theater of the tournament for the Liberazione tentata da Venere. Bologna 20 March 1628. Source: G.B. Coriolanus in Fagiolo M. (ed.), Le capitali della Festa. Italia centrale e meridionale, Roma, Italia [20].

The vision of the theater tournament "The triumph of virtue", held in Modena (Italy) in 1660 shows part of a group of planks prepared for a party with weapons on horses, drawn by Girolamo Graziani. The enclosure seems to have a structured circular shape with stages in the lower part and two levels of sceneries in the upper one. (See Figure 14)

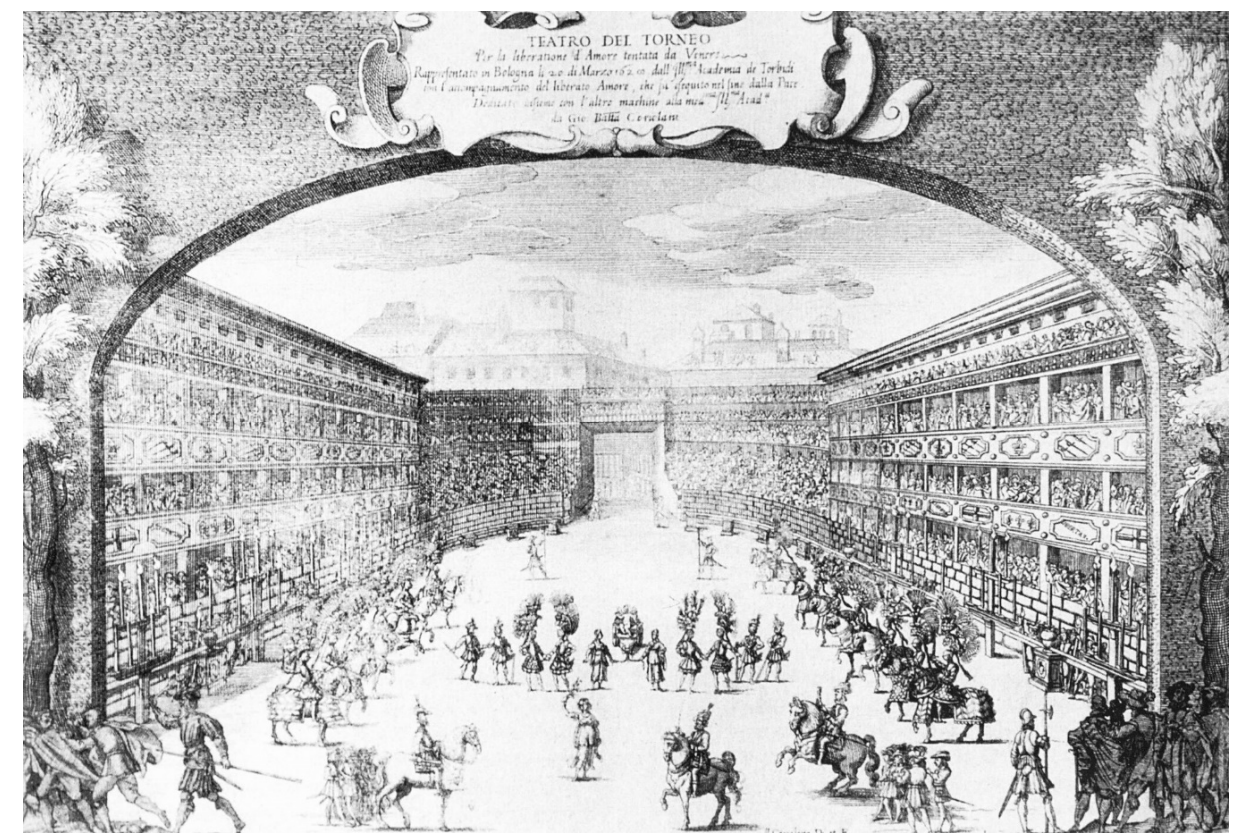

Figure 14. Table on the Triumph of Virtue Modena 1660 of Girolamo Grazian, in Fagiolo M. (Ed.) L'effimero Bolognese, Italia [21].

The engraving made by F. De Grado; for the preparation of the party for the tournament in the Royal Palace Square, held on 4 May 1690 by Luca Antonio di Natale, a military Italian engineer and architect, on the wedding of King Carlos II and the princess Ana Maria de Neoburgus, shows a rectangular enclosure that incorporates galleries and stairs in multiple levels. In the scene center, there are equestrian games where the most interesting element, because of its relationship with bullring, is 
the presence of bullfighting, which is expressly indicated in the lower part of the same perspective "caza de toros". (See Figure 15)

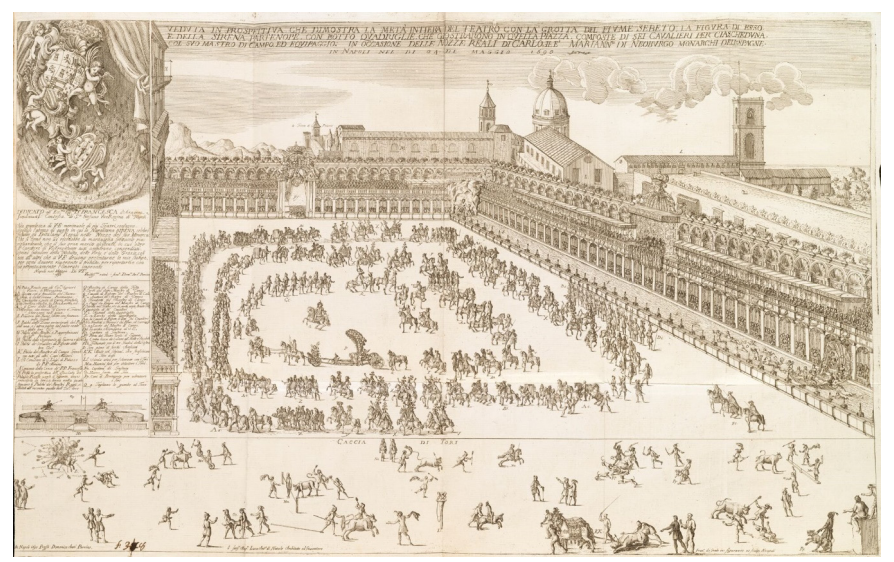

Figure 15. Festival Representation for tournaments in the Plaza del Royal Palace, 1690 of F. De Grado in Parrino D.A. (ed.), L'ossequio tributario della fedelissima città di Napoli per le dimostranze giulive nei regii sponsali del cattolico, ed invittissimo monarca Carlo secondo colla serenissima principessa di Neoburgo palatina del Reno..., Napoli, Italia 1690 [22].

The engraving by P. Maggio for the tournament in the Piazza Marina in Palermo (Italy), on the marriage of Carlos II and Maria Luisa de Borbon in 1680, presents an elliptical fence built on models of the Roman amphitheaters with stages and sceneries. (See Figure 16)

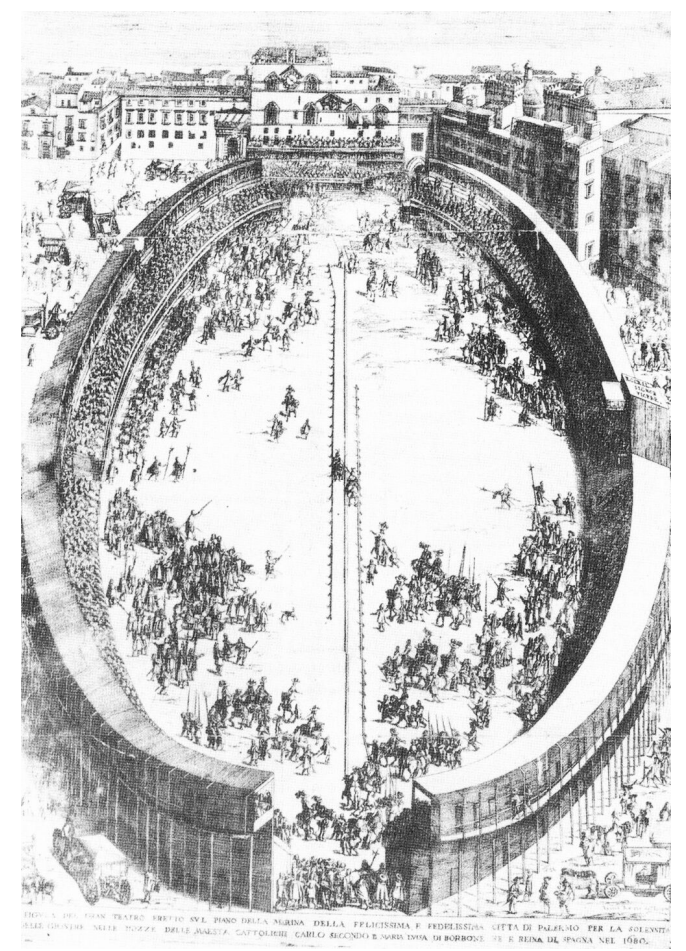

Figure 16. Bull hunting for the Tournament in Plaza Marina in Palermo, 1680 of P. Maggio in Fagiolo M. (Ed.) Le Capitali Della Festa; Italia Centrale e Meridionale, Roma, Italia [23].

Fences with a variety of solutions are those made on the Festa della Porchetta in Bologna, which is repeated more than 140 times between 1597 and 1796. A study about the Bologna Festival reveals 
how a designed component for the enclosure is a rectangular planimetric system that alternates oval or semicircular mix-lineal solutions in a few cases, but in most cases, a solution of open fences [24] is presented.

\section{Conclusions}

Considering the festival models offered by the Baroque culture, it is good to enquire what role Roman constructions have played in the circus-theater; rediscovered so far in time with the advent of neoclassical culture; and up to what extent the experience of the party and the ephemeral enclosures for the spectacle have influenced structuring and definition of the Plaza de Toros in Spain and, thus, Colombian Corralejas.

Based on the reflections made, it can be assumed that Corralejas still preserve the ephemeral nature of these architectures for bullfighting in 18th century Spain, when they started to stabilize. The circular shape definition must be sought only partially in the Roman architecture for the spectacle; which certainly influences the experience in the transition from the ephemeral to the stable. While enclosures may have played a significant role for festivities, the Baroque ones had an ephemeral and playful character.

Festival's enclosures-Corralejas-are almost always made for religious celebration too. The Corraleja is a place for spectacle and events, as well as demonstrations of cavalry, celebration and parody. This finds majestic moments with the courtly Baroque in Europe where they acquire, in some cases, a stable character, while a more linked character to the simple local tradition is retained in the Caribbean, becoming extraordinary declensions of a vernacular constructive tradition.

One more substantial difference surely exists among several experiences of bullrings and Corralejas. The first one is developed as an urban place (a true stable square). In the second case, the idea of an ephemeral and nomadic architecture, always well connected with the constructive vernacular tradition, endures. It also coincides, not accidentally, with an outside place in the middle of the countryside, (In Figure 17, Cordovan landscape is a mixture of cattle and nature: before, while and after the ephemeral installation of Corraleja) i.e., a true enclosure of tree's trunks which are domesticated in the Cordoba landscape.
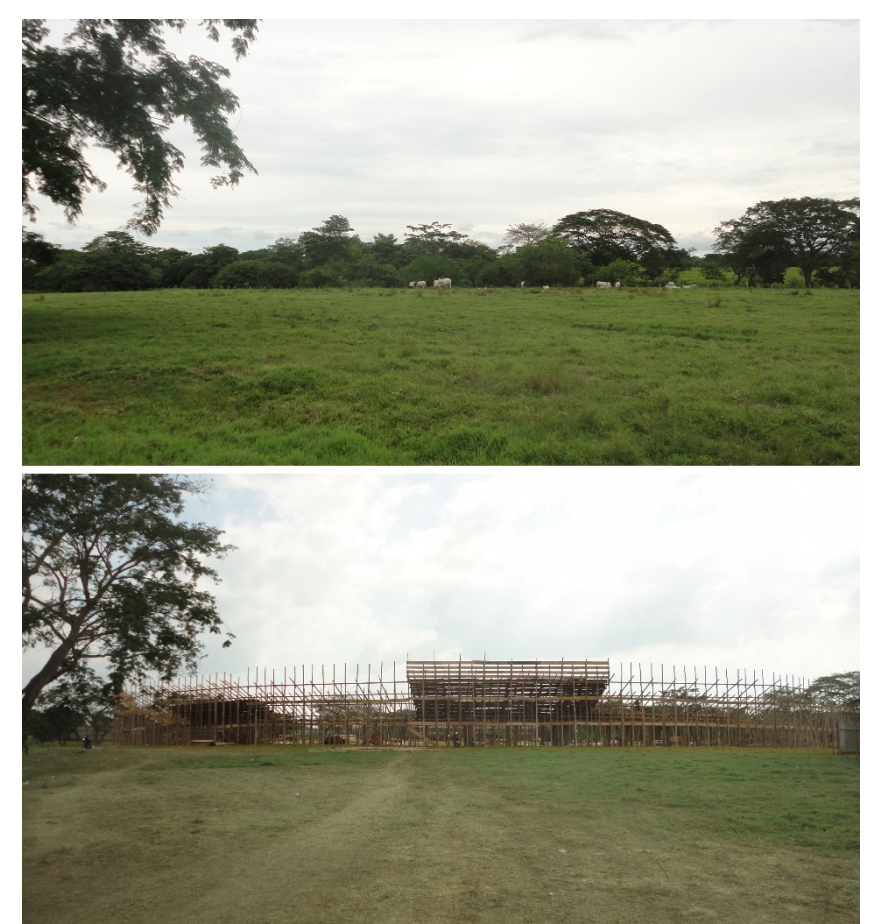

Figure 17. Cont. 


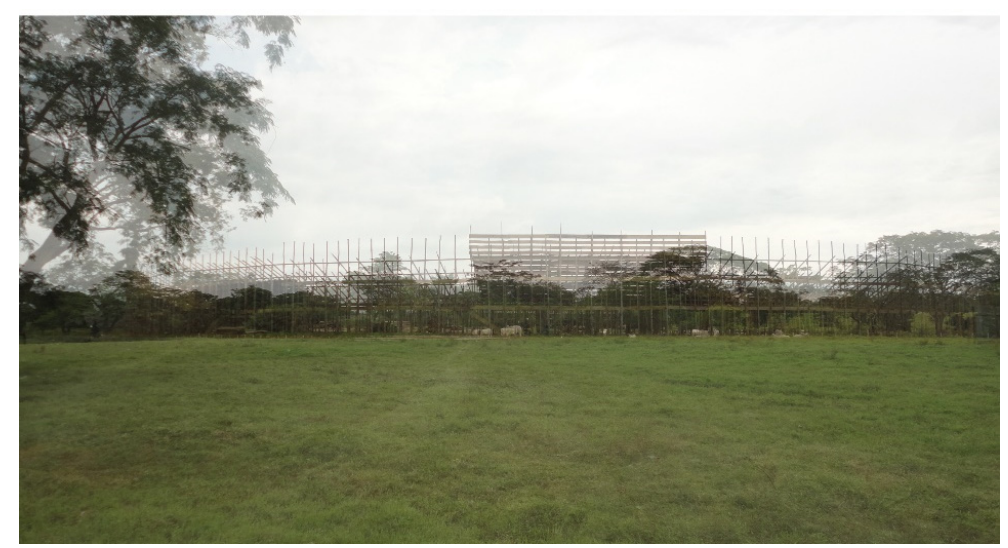

Figure 17. Sequence of images about the installation place of a Corraleja in the Municipality of Planeta Rica-Cordoba. In the Cordoba landscape the presence of cattle as well as nature is constant: before, while and after the ephemeral installation of the Corraleja. Source: Merwan Chaverra, 2017 [14].

The Corraleja represents a unique architectural example of its genre due to its provided characteristics. For this reason, it is necessary to continue doing scientific research on its relevance and scope; simultaneously and forwardly preserving it through a formal declaration of architectural heritage.

Author Contributions: The authors worked as a team all the time, in the project as well as in the article. So, it is not possible to individualize their contributions.

Conflicts of Interest: The authors declare no conflict of interest.

\section{References}

1. Gentil Baldrich, J.M.; Yanguas Álvarez de Toledo, A.; Martín Pastor, A. Introduction, Catalogo de la Exposicion. In Rito y Fiestas. Una Aproximacion a la Arquitectura Efimera Sevillana, 1st ed.; Fidas-Coas: Sevilla, Spain, 2004; p. 166. ISBN 8493373826.

2. Centro de Documentación Regional Orlando Fals Borda-Banco de la República Montería. Folder, p. 23.

3. Pallasmaa, J. Sabiduria Existencial y Corporal en la Arquitectura. La Mano que Piensa, 6th ed.; Gustavo Gili: Barcelona, Spain, 2012; p. 8. ISBN 9788425223273.

4. Leserri, M. Personal Photografic Archive Monteria. 2017.

5. Ugo, V.; Masiero, R. Eticitá e Passione. Saggio su Laugier e L'imitazione. Laugier e la Dimensione Teorica Dell'architettura, 1st ed.; Edizioni Dedalo: Bari, Italy, 1990; pp. 198-199. ISBN 882206092X.

6. Oliva, G. L'esperienza del Paesaggio. Architettura e Paesaggio. Riflessioni, 1st ed.; Nuova Cultura: Roma, Italy, 2012; p. 67. ISBN 9788861348028.

7. Corral: Broader and Roofless Enclosures Are Also Known as Corral, Where for Some Purposes, Horses, Cows, Bulls, or Even Exotic or Other Animals Are Housed; Which, Due to Their Low Aggressiveness, Allow Their Containment in This Type of Space Simply Closed. Real Académia Española. Disponible en línea. Available online: http:/ / dle.rae.es/?id=Awe9N3e (accessed on 27 November 2017).

8. Hemingway, E. Muerte en la Tarde, 1st ed.; Editorial Planeta: Barcelona, Spain, 1977; ISBN 8432021628.

9. Santana Vega, J.A. El Mundo de La Corraleja; Editorial Graficas Corsa of Monteria: Monteria, Colombia, 1986; p. 58.

10. Fonseca, L.; Saldarriaga, A. Cit. The largest percentage of the architecture that exists and that is built daily in Colombia is produced by the popular communities. In Lo Popular en Arquitectura, Arquitectura Popular en Colombia, Herencias y Tradiciones, 1st ed.; Altamir Ediciones: Bogotá, Colombia, 1992; p. 15. ISBN 9589232183.

11. Alexander, C. Lenguaje de Patrones, 1st ed.; Gustavo Gili, S.A.: Barcelona, Spain, 1980; ISBN 9788425209857.

12. Semper, G. The Four Elements of Architecture and Other Writings, 1st ed.; Cambridge University Press: Cambridge, UK, 1989; ISBN 0521354757.

13. Santana, J. El Mundo de las Corralejas, 1st ed.; Caja de Previsión Social de Córdoba: Montería, Colombia, 1986. 
14. Chaverra Suarez, M. Personal Grafic Archive Monteria. 2017.

15. Arènes de Nimes à Nimes et nulle part ailleurs. Available online: http:/ / arenesdenimes.com (accessed on 2 March 2018).

16. Gentil Baldrich, J.M.; Yanguas Álvarez de Toledo, A.; Martín Pastor, A. Plano del la plaza de San Francisco preparada con tribuna para plaza de toro, Catalogo de la Exposicion. In Rito y Fiestas. Una Aproximacion a la Arquitectura Efimera Sevillana, 1st ed.; Fidas-Coas: Sevilla, Spain, 2004; Volume 1, p. 238. ISBN 8493373826.

17. Alvarez, H.; Ossorio, F. Evolucion de las formas arquitectonicas de una plaza de toros: Plaza de toros de la Real Maestranza de Caballeria de Sevilla. Revista de Estudios Taurinos 1996, 4, 95-124.

18. Alvarez, H.; Ossorio, F. Evolucion de las formas arquitectonicas de una plaza de toros: Plaza de toros de la Real Maestranza de Caballeria de Sevilla. Revista de Estudios Taurinos 1997, 5, 53-77.

19. Alvarez, H.; Ossorio, F. Fiestas de Toros y Sociedad. La Plazas de Toros de los Virreinatos de America, Actas del Congreso International, España, 26 de Noviembre al 1 de Diciembre 2001; Garcia-Baquero Gonzales, A., Romero de Solis, P., Eds.; Universidad de Sevilla: Sevilla, Spain, 2001; pp. 707-718.

20. Pigozzi, M. Apparati festivi nel ducato di Modena e Reggio Emilia. In Atlante Tematico del Barocco in Italia. Le Capitali Della Festa Italia Centrale e Meridionale; Fagiolo, M., Ed.; De Luca Editori d'arte: Roma, Italy, 2007; p. 59. ISBN 9788880168447.

21. Pigozzi, M. L'effimero bolognese. In Atlante Tematico del Barocco in Italia. Le Capitali Della Festa Italia Centrale e Meridionale; Fagiolo, M., Ed.; De Luca Editori d'arte: Roma, Italy, 2007; p. 17. ISBN 9788880168447.

22. Cantone, G. Napoli: la festa e la città. In Atlante Tematico del Barocco in Italia. Le Capitali Della Festa Italia Centrale e Meridionale; Fagiolo, M., Ed.; De Luca Editori d'arte: Roma, Italy, 2007; p. 288. ISBN 9788880168447.

23. Di Fede, M.S. La festa barocca a Palermo. In Atlante Tematico del Barocco in Italia. Le Capitali Della Festa Italia Centrale e Meridionale; Fagiolo, M., Ed.; De Luca Editori d'arte: Roma, Italy, 2007; p. 379. ISBN 9788880168447.

24. Leotti Umberto, Schedatura Della Festa Della Porchetta per Un'analisi Computerizzata. In Atlante Tematico del Barocco in Italia. Le Capitali Della Festa Italia Centrale e Meridionale; Fagiolo, M., Ed.; De Luca Editori d'Arte: Roma, Italy, 2007; pp. 33-44. ISBN 9788880168447.

(C) 2018 by the authors. Licensee MDPI, Basel, Switzerland. This article is an open access article distributed under the terms and conditions of the Creative Commons Attribution (CC BY) license (http:/ / creativecommons.org/licenses/by/4.0/). 